\title{
Type IV resistant starch increases cecum short chain fatty acids level in rats*
}

\author{
Joanna Le Thanh-Blicharz ${ }^{\circledR}$, Jacek Anioła², Przemysław Kowalczewski ${ }^{3}$, Krzysztof \\ Przygoński ${ }^{1}$, Zofia Zaborowska ${ }^{1}$ and Grażyna Lewandowicz ${ }^{3}$
}

'Department of Food Concentrates and Starch Products in Poznań, Institute of Agricultural and Food Biotechnology, Warszawa, Poland; ${ }^{2}$ Department of Human Nutrition and Hygiene, Poznań University of Life Sciences, Poznań; ${ }^{3}$ Department of Biotechnology and Food Microbiology, Poznań University of Life Science, Poznań, Poland

Resistant starches are type of dietary fibers. However, their physiological effects depend on the way they resist digestion in the gastrointestinal tract. The objective of this study was to examine the hypothesis that new type of RS4 preparations, of in vitro digestibility of about $50 \%$, obtained by cross-linking and acetylation, acts as a prebiotic by increasing short chain fatty acids content in cecum digesta. The rats were fed with diet containing pregelatinized, cross-linked and acetylated starches as a main carbohydrate source. Pregelatinized, but not chemically modified, potato starch was used in the composition of the control diet. After two weeks of experiment the increase of short chain fatty acids contents in ceceum digesta was observed. The intake of starch A, cross-linked only with adipic acid, resulted in increase of about $40 \%$ of short chain fatty acids content, whereas starch PA cross-linked with sodium trimetaphosphate and adipic acid of about $50 \%$. The utmost twofold increase was observed in the case of the production of propionic acid. In contrast, the content of butyric acid increased $(12 \%)$ only as an effect of consumption of starch PA and even decreased (about 30\%) in case of starch A. Both RS4 starches caused an increase of the production of acetic acid by more than $40 \%$. No changes in serum biochemistry, liver cholesterol and organ weights of rats were stated.

Key words: type IV resistant starch, digestibility, rats, short chain fatty acids, prebiotic

Received: 24 October, 2013; revised: 19 February, 2014; accepted: 21 February, 2014; available on-line: 19 March, 2014

\section{INTRODUCTION}

The nutritional properties of starch in foods are to a large extent related to its availability for digestion and/ or absorption in the gastrointestinal tract. From this point of view, starch can be classified into three basic groups: rapidly digestible starch (RDS), slowly digestible starch (SDS), and resistant starch (RS) (Englyst \& Hudson, 1996). Several authors hold the view that enzyme resistant starch should be included in dietary fiber because of its physiological properties which are similar to certain fiber polysaccharides (Leszczyński, 2004; Soral-Śmietana \& Wronkowska, 2004; Anderson et al., 2009; Fuentes-Zaragoza et al., 2010; Fuentes-Zaragoza et al., 2011). Dietary fiber is a collective term for several natural components that are resistant to hydrolysis by digestive enzymes of humans; this includes polysaccha- ride and lignin (Napolitano et al., 2009; Fuentes-Zaragoza et al., 2010). Not digested substances are substrates for colonic fermentation that produces short chain fatty acids (SCFAs), such as acetic, butyric and propionic acids (Napolitano et al., 2009). A large intake of dietary fiber improves serum lipid concentration, lowers blood pressure, improves blood glucose control in diabetes, aids in weight loss and appears to improve immune function. Furthermore, increased consumption of dietary fiber reduces risk of developing coronary heart disease, stroke, hypertension, diabetes, obesity and certain gastrointestinal diseases (Anderson et al., 2009, Dżymała-Czyż et al., 2011). Physiological effect of dietary fiber depends on its physicochemical properties mainly on solubility. Insoluble dietary fibers are generally more resistant to colonic fermentation than soluble ones, so their physiological effect is less pronounced. There are a lot of methods for determination of prebiotic potential of dietary fiber, however, all of them are still incomplete. Most of the recommended procedures are based on determination of the growth of probiotic bacteria from genera Lactobacillus or Bifidobacterium and evaluation of the amount of shortchain fatty acids produced by them. However, there are no uniform standards for in vitro studies (Ewards et al. 1996, Bielecka et al. 2002, Wronkowska et al. 2006).

Resistant starches are important components of the human diet. However, their physiological effects differ and depend on the way they avoid digestion in the gastrointestinal tract. From this point of view resistant starch has been classified into four types (Cummings \& Stephen, 2007; Sharma et al., 2008):

Type I (RS1): Physically inaccessible starch locked in the plant cell, mostly present whole grains.

Type II (RS2): Native starch granules from certain plants (i.e., potato and high amylose maize)

Type III (RS3): Retrograded, crystalline, nongranular starch formed after cooking (e.g., cooked and cooled potatoes, cornflakes)

Type IV (RS4): The chemically modified or re-polymerized starches. Chemical conversion, substitution, and cross-linking results in the formation of atypical linkages,

e-mail: lethanh@man.poznan.pl

*Presented at the 3-rd Workshop on Microbiology "MIKROBIOT $2013^{\prime \prime}$ in Łódź, Poland.

Abbreviations: EDTA, ethylenediaminetetraacetic acid; FID , flameionization detector; HDL, high-density lipoprotein cholesterol; HPLC, high-performance liquid chromatography A, starch modified by cross-linking with adipic acid and by acetylation; RDS, rapid digestible starch; RS, resistant starch; SCFA, short chain fatty acids; SDS, slowly digestible starch; TC, total cholesterol; TG, triacylglyceride; PA, starch modified by dual cross-linking with trimetaphosphate and adipic acid, and by acetylation 
and prevents digestion by blocking enzyme access. It includes dextrins, ethers, or esters.

Recently, the fifth type of resistant starch has been proposed. It includes amylose-lipid complexes which are formed especially effective in the presence of high amylose maize starch (Fuentes-Zaragoza et al., 2011). There are commercially available resistant starch products including Hi-maize ${ }^{\circledR}$ whole grain flour (RS1 and RS2), Hi-maize $260^{\circledR}$ corn starch (RS2) and Novelose ${ }^{\circledR}$ resistant starch (Fuentes-Zaragoza et al., 2010). Their technological applicability diminishes low water solubility and no thickening or stabilizing effect in food products is observed. There are also offered fully soluble resistant starch products Nutriose ${ }^{\circledR}$ and Fibersol ${ }^{\circledR}$ (ADM / Matsutani LLC) based on dextrins (Xie et al., 2006). In spite of full solubility these products are also characterized by the low thickening capability. Consequently, there is a lack on the market of the dietary starches revealing appropriate functionality in formation of the texture of food products. Therefore, different research groups are working on novel RS4 products which seems to be the most promising in terms of formation of appropriate texture of food products (Mun et al., 2006; Xie et al., 2006; Kim et al., 2008; Zhang \& Wang, 2009; Zięba et al., 2011a; Zięba et al., 2011b; Sha et al., 2012). In our previous works we found that new type of RS4 preparations, of in vitro digestibility not exceeding $50 \%$, obtained by cross-linking and acetylation reveals excellent rheological properties (Le Thanh-Blicharz et al., 2012). Furthermore, in vivo studies showed no changes in diet intake, body weight gain, apparent diet digestibility, apparent protein, fat or carbohydrates digestibility in Wistar rats fed with diet containing $50 \%$ of these RS4 preparation. During that time, an increase of defecation and water content in cecum digesta as well as decrease in transit time are observed. We hypothesize that our new type of RS4 preparations, of in vitro digestibility of ca. $50 \%$, obtained by cross-linking and acetylation, acts as a prebiotic by increasing short chain fatty acids content in cecum digesta. The aim of this work was to verify this hypothesis in the experiment using the Wistar rats. Absorption of minerals as well as glucose, triacylglyceride, and cholesterol contents in serum and liver were also determined.

\section{METHODS AND MATERIALS}

Modified starches. Two cross-linked and acetylated starches were investigated. Starch A was modified by esterification with adipic and acetic acids, according to the procedure described in detail in our previous work (Le Thanh-Blicharz et al., 2011). Starch PA, previous to esterification with adipic and acetic acids, was crosslinked with sodium trimetaphosphate (Le Thanh-Blicharz et al., 2011). Starch A contained 0.115 $\pm 0.004 \%$ of adipic groups, $0.88 \pm 0.04 \%$ of acetic groups, and $0.0569 \pm 0.0001 \%$ of phosphorus; starch PA contained $0.117 \pm 0.014 \%, 0.29 \pm 0.03 \%$, and $0.0641 \pm 0.0004 \%$, respectively.

Commercial pregelatinized potato starch (ZETPEZET Piła Poland) was used as a fully digestible carbohydrate source.

Animals. Thirty 12 weeks old male Wistar rats with initial body weight about $340 \mathrm{~g}$ were purchased from Poznan University of Medical Science. Animals were placed individually in stainless steel wire mesh cages in room maintained at $21^{\circ} \mathrm{C} \pm 2{ }^{\circ} \mathrm{C}$, on a $12 \mathrm{~h}$ light-dark cycle, according to internationally accepted guidelines. All animals were treated in the humane way in accordance
Table 1. Diet composition $(\mathrm{g} / \mathrm{kg})$

\begin{tabular}{lccc}
\hline Ingredient of the diet $[\mathrm{g} / \mathrm{kg}]$ & Control & A & PA \\
\hline Casein & 200 & 200 & 200 \\
\hline Sucrose & 100 & 100 & 100 \\
\hdashline Sunflower oil & 100 & 100 & 100 \\
\hline Native potato starch & 55 & 55 & 55 \\
\hline Pregelatinized potato starch & 500 & - & - \\
\hline Modified starch A & - & 500 & - \\
\hdashline Modified starch PA & - & - & 500 \\
\hline Vitamin mix & 10 & 10 & 10 \\
\hline Mineral mix & 35 & 35 & 35 \\
\hline
\end{tabular}

${ }^{a}$ cholecalciferol 200 jm; vitamin K 0.5 mg; 4-aminobenzoic acid 200 mg; inositol $10 \mathrm{mg}$; niacin $10 \mathrm{mg}$; calcium pantothenle $4 \mathrm{mg}$; ryboflavin 4 $\mathrm{mg}$; tiamine $0.8 \mathrm{mg}$; pyridoxine $0.5 \mathrm{mg}$; folic acid $0.2 \mathrm{mg}$; biotin 0.04 $\mathrm{mg}$; cabalamin $0.003 \mathrm{mg}$; glucose up to $1000 \mathrm{mg}$.

bdicalcium phosphate - $735 \mathrm{~g} / \mathrm{kg}$; potassium phosphate $81.0 \mathrm{~g} / \mathrm{kg}$; potassium sulphate $68.0 \mathrm{~g} / \mathrm{kg}$; sodium chloride $21.0 \mathrm{~g} / \mathrm{kg}$; disodium hydrogen phosphate $21.4 \mathrm{~g} / \mathrm{kg}$; magnesium oxide $25.0 \mathrm{~g} / \mathrm{kg}$; mineral mixture $18 \mathrm{~g} / \mathrm{kg}$ : (ferrum citrate $31.0 \mathrm{~g} / \mathrm{kg}$, zinc carbonate $4.50 \mathrm{~g} / \mathrm{kg}$, magnese carbonate $23.4 \mathrm{~g} / \mathrm{kg}$, copper carbonate $1.85 \mathrm{~g} / \mathrm{kg}$, potassium iodide $0.04 \mathrm{~g} / \mathrm{kg}$, citric acid $39.21 \mathrm{~g} / \mathrm{kg}$ ).

with the World Health Organization's guideline for animal care, and the animal study design was approved by the Local Bioethical Committee on Animal Research at the Department of Animal Physiology and Biochemistry, Poznan University of Life Sciences.

The animals were divided into three groups $(n=10)$ by randomized block design according to the weight.

One of the groups received a control diet containing pregelatinized potato starch (Table 1), and the other 2 groups received the same diet in which pregelatinized potato starch was replaced by pregelatinized modified starch A (diet A) or pregelatinized modified starch PA (diet PA). Each ingredient in the diet was weighed and mixed. The mixture was then formed into equally sized pellets and placed into a temperature- and humidity controlled room. Each of three diet was prepared in one bath for the entire experimental period. The formulation of the diets is given in Table 1. The rats received water and pellets ad libitum. During the experimental period, body weight and feed intake were monitored. Faeces were collected every day and stored at $5^{\circ} \mathrm{C}$.

Collection of blood and internal organ samples. At the end of the test (day 14 of the experiment) and after 16 hours of starvation, the animals were weighed and euthanized by intraperitoneal injection of thiopental (40 mg/kg body weight). They were dissected to collect blood for biochemical studies and to harvest and clean their internal organs (e.g., heart, liver, spleen, kidneys, testicle) for weight assessment. Blood samples were collected into clean test tubes containing ethylenediaminetetraacetic acid EDTA, centrifuged $(3500 \times g$ for 10 minutes, $4^{\circ} \mathrm{C}$ ), and stored at $20^{\circ} \mathrm{C}$ for determination of the serum lipids: total cholesterol (TC), high-density lipoprotein cholesterol (HDL), and triacylglyceride (TG).

Serum glucose and lipids profile analyses. Serum glucose, total cholesterol, HDL, and TG concentrations were determined by colorimetric methods (Clinical and Laboratory Standards Institute, 2004) using Olympus AU 560 equipment (Olympus Japan, Tokyo, Japan).

Fecal and liver tissue cholesterol concentrations were determined by HPLC method. The samples ( $0.5 \mathrm{~g}$ of homogenized liver or feces) were placed in centrifuge 
tubes with $3 \mathrm{ml}$ of $60 \% \mathrm{KOH}$ water solution, vortex and saponified for $60 \mathrm{~min}$ at $80^{\circ} \mathrm{C}$. After cooling, $2 \mathrm{ml}$ of $5 \% \mathrm{NaCl}$ and $4 \mathrm{ml}$ of $10 \%$ ethyl acetate in $\mathrm{n}$-hexane were added and vortex. $1 \mathrm{ml}$ of $\mathrm{n}$-hexane layer was taken to chromatography vials and analyzed. A Merck Hitachi high performance liquid chromatography HPLC system LaChrom was used with L-7455 DAD detector and LiChroCART 250-4, Si $60(5 \mu \mathrm{m})$ column. Eluent: hexane, $2 \mathrm{ml} / \mathrm{min}$, detection wavelength: $202 \mathrm{~nm}$, retention time: $40 \mathrm{~min}$.

Short chain fatty acid (SCFA) measurement. The short chain fatty acids contents in cecum digesta was analyzed according to Zhao et. al (2006), using a gas chromatography (Heweltt-Packard, Germany) with a flame-ionization detector (FID) and a Supelco Nukol fused silica capillary column $(30 \mathrm{~mm} \times 0.25 \mathrm{~mm}$ i.d.; $0.25 \mu \mathrm{m})$. Helium was used as a carrier gas with a flow rate of $100 \mathrm{ml} / \mathrm{min}$. The oven was initially kept at $100^{\circ} \mathrm{C}$ for $2 \mathrm{~min}$, then heated in intervals of $10^{\circ} \mathrm{C}$ to $150^{\circ} \mathrm{C}$ and held for $15 \mathrm{~min}$. The injector temperature was maintained at $220^{\circ} \mathrm{C}$, while the detector was kept at $240^{\circ} \mathrm{C}$. The total run time was approximately $20 \mathrm{~min}$. The concentration of individual SCFA was estimated in relation to IS using a mixture of SCFA standard solutions (Supelco); 2-ethylbutyric acid was used as internal standard.

Statistical analysis. Results were expressed as a mean and SD values. All data were analyzed using Statistica Software (version 10.0 PL; Statsoft, inc. Poland). Oneway analysis of variance was used to determine the significance of the differences amongst groups, followed by post-hoc Scheff's test. A P value of less than 0.05 was regarded as significant.

\section{RESULTS}

The intake of different diets by experimental rats did not result in significant differences in their serum biochemistry (Table 2). The serum glucose content was on the level of $117-128(\mathrm{mg} / \mathrm{dL})$, triacylglyceride $46.3-50.0$ $(\mathrm{mg} / \mathrm{dL})$, total cholesterol 77-89 (mg/100ml), and highdensity cholesterol 61.4-64.6 (mg/dL). A significant increase in fecal TC excretion as an effect of resistant starch intake was observed - of about $10 \%$ in case of group fed with starch PA, and of nearly 30\% in case of rats fed with diet A. However, these changes did not affect the liver triacylglyceride content which was on the level of 232-262 (mg/100g).

Similarly, the intake of different diets by experimental rats did not result in significant differences (by probability $<0.05$ ) in organ weights of rats (Table 3 ). The ratio of the weight of heart to the weight of body was 0.28

Table 2. Serum biochemistry, fecal TC excretion and liver TC content of the treatment and control groups

\begin{tabular}{llll}
\hline & Control & A & PA \\
\hline $\begin{array}{l}\text { Serum glucose }(\mathrm{mg} / \\
\mathrm{dL})\end{array}$ & $128 \pm 15$ & $117 \pm 14$ & $133 \pm 14$ \\
\hdashline Serum TG $(\mathrm{mg} / \mathrm{dL})$ & $46.3 \pm 7.2$ & $47.6 \pm 13.6$ & $50.0 \pm 19.0$ \\
\hline Serum TC $(\mathrm{mg} / \mathrm{dL})$ & $89 \pm 12$ & $77 \pm 25$ & $81 \pm 22$ \\
\hdashline Serum HDL $(\mathrm{mg} / \mathrm{dL})$ & $64.6 \pm 13.8$ & $61.4 \pm 11.9$ & $62.6 \pm 7.7$ \\
\hline $\begin{array}{l}\text { Fecal TC excretion } \\
\text { (mg/24h) }\end{array}$ & $2.69 \pm 0.45^{\mathrm{a}}$ & $3.42 \pm 0.79^{\mathrm{b}}$ & $2.99 \pm 0.58^{\mathrm{ab}}$ \\
\hdashline Liver TC $(\mathrm{mg} / 100 \mathrm{~g})$ & $237 \pm 22$ & $262 \pm 86$ & $232 \pm 26$ \\
\hline
\end{tabular}

The means in the column with different superscripts are significantly different $(P<0.05)$.
Table 3. Organ weight of rats fed the treatment and control diet

\begin{tabular}{llll}
\hline & Control & A & PA \\
\hline $\begin{array}{l}\text { Heart weight/body } \\
\text { weight ratio (\%) }\end{array}$ & $0.30 \pm 0.01$ & $0.29 \pm 0.01$ & $0.28 \pm 0.01$ \\
\hdashline $\begin{array}{l}\text { Liver weight/body } \\
\text { weight ratio (\%) }\end{array}$ & $3.21 \pm 0.27$ & $3.32 \pm 0.36$ & $3.16 \pm 0.30$ \\
\hline $\begin{array}{l}\text { Cecum weight/body } \\
\text { weight ratio (\%) }\end{array}$ & $0.9 \pm 0.21$ & $1.0 \pm 0,22$ & $1.0 \pm 0.21$ \\
\hline $\begin{array}{l}\text { Intestine weight/body } \\
\text { weight ratio (\%) }\end{array}$ & $0.17 \pm 0.08$ & $0.16 \pm 0.08$ & $0.14 \pm 0.07$ \\
\hline $\begin{array}{l}\text { Spleen weight/body } \\
\text { weight ratio (\%) }\end{array}$ & $0.19 \pm 0.01$ & $0.19 \pm 0.01$ & $0.19 \pm 0.02$ \\
\hline $\begin{array}{l}\text { Kidneys weight/body } \\
\text { weight ratio (\%) }\end{array}$ & $0.66 \pm 0.03$ & $0.66 \pm 0.03$ & $0.65 \pm 0.03$ \\
\hline $\begin{array}{l}\text { Testicle weight/body } \\
\text { weight ratio (\% ) }\end{array}$ & $1.04 \pm 0.10$ & $1.04 \pm 0.15$ & $1.07 \pm 0.03$ \\
\hline
\end{tabular}

Table 4. Cecal digesta total short chain fatty acids (SCFA) pool of rats fed experimental diets

\begin{tabular}{lllll}
\hline & Control & A & PA & $\begin{array}{l}\text { Signifi- } \\
\text { cance }\end{array}$ \\
\hline $\begin{array}{l}\text { Acetic acid } \\
\left(\mathrm{mMol} / \mathrm{dm}^{3}\right)\end{array}$ & $2.18 \pm 0.52^{\mathrm{a}}$ & $3.14 \pm 1.37^{\mathrm{b}}$ & $3.11 \pm 1.24^{\mathrm{b}}$ & $\mathrm{p}<0.05$ \\
\hdashline $\begin{array}{l}\text { Propionic } \\
\text { acid (mMol/ } \\
\left.\mathrm{dm}^{3}\right)\end{array}$ & $0.39 \pm 0.11^{\mathrm{a}}$ & $0.79 \pm 0.25^{\mathrm{b}}$ & $0.82 \pm 023^{\mathrm{b}}$ & $\mathrm{p}<0.001$ \\
\hline $\begin{array}{l}\text { Butyric acid } \\
\left(\mathrm{mMol} / \mathrm{dm}^{3}\right)\end{array}$ & $0.41 \pm 0.13^{\mathrm{ab}}$ & $0.30 \pm 0.13^{\mathrm{a}}$ & $0.46 \pm 0.22^{\mathrm{b}}$ & $\mathrm{p}<0.05$ \\
\hdashline \begin{tabular}{l}
\hline $\mathrm{SCFA}$ \\
$\left(\mathrm{mMol} / \mathrm{dm}^{3}\right)$
\end{tabular} & $2.99 \pm 0.70^{\mathrm{a}}$ & $4.23 \pm 1.62^{\mathrm{b}}$ & $4.40 \pm 1.55^{\mathrm{b}}$ & $\mathrm{p}<0.05$ \\
\hline
\end{tabular}

0.3 liver 3.16-3.32, cecum 0.9-1.0, intestine 0.14-1.17, spleen 0.19 , kidneys 065-0.66, and testicle 1.04-1.07, respectively.

The intake of the diet containing resistant starch resulted in significant increase of the short chain fatty acids production in the digestive system of rats (Table 4). The increase of the sum of SCFA was of about $40 \%$ in case of starch A and nearly $50 \%$ in case of starch PA. The utmost increase (twofold in case of starch A or more in case of starch PA) was observed in case of propionic acid. In contrast, the content of butyric acid increased $(12 \%)$ only as an effect of consumption of starch PA and even decreased (about 30\%) in case of starch A. Both RS4 starches caused increase of the production of acetic acid of more than $40 \%$.

\section{DISCUSSION}

There are a lot of in vivo studies on the physiological effect of resistant starch (Björk et al., 1989; De Deckre et al., 1993; Lajvardi et al., 1993; Marlett \& Longacre, 1996; Morais et al., 1996; Ranhotra et al., 1997; Vanhoof \& De Schrijver, 1997; Ebihara et al., 1998; Vanhoof \& De Schrijver, 1998; De Schrijver et al., 1999; Cheng \& Lai, 2000; Ferguson et al., 2000; Kishida et al., 2001a; Lopez et al., 2001; Juśkiewicz et al. 2005; Satniek et al., 2005; Kanazawa et al., 2008; Anioła et al., 2009; Orzel et al., 2009; Wronkowska et al., 2011; Lee et al., 2012). However, the results published by different research groups are difficult to compare. It is mainly due to different conditions of experiments carried out by each group. Moreover, there is also very important but often neglected reason — the way that resistant starch avoid digestion 
in the gastrointestinal tract. Different types of resistant starch are characterized by different structures and physicochemical properties, so their physiological effect must differ as well.

Digestibility is the most important and very often determined in vitro parameter of resistant starch products. Unfortunately, in vivo experiments almost always gives much higher than those obtained in vitro (Wootton \& Chaudhry, 1979; Björk et al. 1989; Marlett \& Longacre, 1996). This pertains especially type IV of resistant starch. All protocols for the in vitro determination of resistant starch content or starch digestibility require a determination of the glucose released after hydrolysis catalyzed by $\alpha$-amylase and glucoamylase (Champ, 1992; Englyst \& Hudson, 1996; Le Thanh et al., 2007; Perera et al., 2010). Other than $\alpha-1,4-$ and $\alpha-1,6$-glycosidic bonds, i.e. bonds not hydrolyzed by amylolytic enzymes could be digested by other gut enzymes, which increases the in vivo analyses results (Clarke et al., 2007). This is particularly in case of starch phosphates and acetates. More difficult are hydrolyzed ether bonds in hydroxypropylstarches (Marlett \& Longacre, 1996; Clinical and Laboratory Standards Institute 2004). In contrast to substitution with ester groups, crystal structure of starch more significantly affects its digestibility in vivo. Native RS2 as well as retrograded RS3 starches are digested at most in 70\% (Björk et al. 1989).

The two cross-linked and acetylated starches were used in the presented study. The low values of their degree of substitution with acetyl and adipate groups make it so that both starches fulfill JECFA recommendations for modified starch INS 1422. Furthermore, phosphorus content in PA starch fulfill JECFA recommendations for modified starch INS 1412 (Compendium of food additive specifications, 1997). However, there are no recommendations for food uses of dual cross-linked starch with trimetaphosphate and adipic anhydride. The degree of cross-linking with adipate groups of the both modified starches did not differ, but corresponded to one cross-linking bond per 770 anhydroglucose units. The degree of cross-linking of the PA starch with phosphate groups was even lower and corresponded to one phosphate group per 2770 anhydroglucose units. That makes both starches able to dissolve in water in the temperature below $100^{\circ} \mathrm{C}$. In other words, there is no need to apply sterilization to dissolve these starches. This also gives them excellent thickening capability. Investigated starches differed also in acetyl groups content which could be important in terms of their digestibility (Le Thanh-Blicharz et al., 2011). The degree of substitution with acetyl groups of starch A corresponded to one acetyl groups per 30 anhydroglucose units, whereas of PA starch corresponded to one acetyl group per 90 anhydroglucose units. However, as it was described in our previous work, modified starches A and PA reveal similar in vitro digestibility - 48\% and 44\%, respectively (Le Thanh-Blicharz et al., 2011). In vivo experiment shows significantly higher digestibility, above $90 \%$, of both starches. Nevertheless, the increase of water content in faces as well as reduction of transit time in rats fed with investigated starches are observed (Le Thanh-Blicharz et al., 2012).

Investigated RS4 starches did not reveal significant effect on serum contents of glucose, triacylglyceride, total cholesterol, and high-density cholesterol. There was also no change in liver total cholesterol content., but slight increase in fecal TC excretion (Table 2). Studies carried out by other research groups on the effect of feeding rats with the diets containing RS2 or RS3 pointed to their different physiological effect. RS3 increases serum and decreases liver cholesterol content in rats. It also causes increase in total steroid excretion. At the same experiment RS2 showed a similar effect as cellulose used in the control group (Chezem et al., 1997). Other researches proved, however, that RS2 lowers plasma and liver lipids and improves mineral retention in rats (Lopez et al., 2001). Physiological effect of RS 2 and RS3 also depends on physiological status of rats. There is no effect on cholesterol metabolism in normocholesterolemic rats fed with diets containing RS2 or RS3. On the contrary, in hypercholestrolemic animals, diets containing resistant starch decrease plasma and liver cholesterol contents (Vanhoof \& De Schrijver 1998). Cheng \& Lai (2000) claim that feeding rats with the diet containing resistant rice starch results in the decrease of serum and hepatic cholesterol. However, rice starch used in this experiment contains relatively low amount of RS (maximum content of RS in the rats diet $-1.8 \mathrm{~g} / 100 \mathrm{~g}$ ). The decrease in total serum cholesterol and triacylglycerol contents as an effect of feeding rats with RS3 is reported by de Deckere et al (1993). However, in relation to RS4 there are only results on starch modified with phosphate groups (Kanazawa et al., 2008; Lee et al., 2012). Feeding rats during 5 weeks with the diet containing gelatinized potato starch of extraordinary high level of phosphorus content $(813$ ppm - higher than those of PA preparation used in our study) decreased serum and liver lipids contents (Kanazawa et al., 2008). RS4 preparation modified by cross-linking with sodium trimetaphosphate added to the fodder of high fat diet-induced obese mice significantly reduced their weight gain, as well as improved their lipid profile (Lee et al., 2012). Noteworthy is also the conclusion made by Kishida et al (2001b), that although heat moisture treatment of high amylose corn starch increases its resistant starch content but not influences its physiologic effects in rats.

The intake of investigated modified starches did not affect the weight of internal organs of rats. It could be due to relatively short time of experiment (two weeks). However, reports of other research groups are also inconclusive. In a 4 week study with RS2 and RS3 starches, a decrease of liver weight is stated (Ranhotra et al., 1996; Cheng \& Lai, 2000). Contrary, an increase of liver and decrease of heart weight in rats fed with acid modified starch is observed (Zhou \& Kaplan, 1997). It was also found that it causes a slight increase of liver weight (Ebihra et al., 1998).

The most spectacular effect of the intake of investigated RS4 starches, observed during presented study, was the increase of short chain fatty acids - of about $40 \%$ in case of starch cross-linked only with adipic acids, and $50 \%$ for dual cross-linked one. It is believed that SCFA play a key role in colonic health, mainly in the prevention and management of certain diseases (Ferguson et al., 2000; Ferguson \& Jones, 2000; Clarke et al., 2007; Hijova \& Chmelarova, 2007). SCFA are rapidly absorbed in the cecum and colon with only $5-10 \%$ being excreted in the cecum digesta. Acetate, the principal SCFA in the colon, is readily absorbed and transported to the liver, and therefore less metabolized in the colon (Hijova \& Chmelarova, 2007). However, some bacteria isolated from the human intestine are capable of utilizing acetate for the production of butyrate in the colon (Commane et al., 2005). Butyrate may be more important than the other SCFAs in protection against colon cancer. Various in vitro studies have indicated that butyrate enhances differentiation of cells, affecting the expression of various cancer-related genes, and may stimulate apopto- 
sis of damaged cells as a mechanism for preventing their progression to form neoplastic cells (Ferguson et al., 2000). The investigated RS4 starches caused significant increase, of about $140-150 \%$, in the acetic acid content in cecum digesta. This, however, was not associated with the increase of butyric acid content. The highest increase, of about $200 \%$, was observed in case of propionic acid. Unfortunately, much of the knowledge concerning physiological role of propionates comes from studies of ruminants, and their metabolism in humans is less understood. It was reported that increase production of propionate may inhibit hepatic cholesterol synthesis (Hijova \& Chmelarova, 2007). It is also believed that propionate, likewise butyrate, stimulate human colonic crypt cells and are important energetic material for colonocytes (Ferguson \& Jones, 2000). Similar to presented above differentiation in the SCFAs content is reported in the work of Wronkowska et al (2011). In contrast to our experiment, Wronkowska et al. fed rats with the diet containing not gelatinized starches — both native as well as commercial food grade chemical modified, so the resistance to amylolysis in this experiment comes mainly from granular, crystal, structure of these starches but not from chemical modification. In that experiment, the highest increase of total SCFAs production is observed by intake of native potato starch. Chemical modification causes decrease in the sum of SCFAs production, especially in case of acetylated distarch adipate (Wronkowska et al., 2011). It should be mentioned that acetylation of starch (alone, without cross-linking) does not affect acetic acid but decreases butyric acid production (Wronkowska et al., 2011). During that time, it significantly increased propionic acid production. In our study, no significant differences between both RS4 starches, in the production of acetic and propionic acids were observed. In contrast, butyric acid was very efficiently produced in the bowel of the rats fed with the diet containing PA starch. Therefore, there is a negative correlation between the degree of substitution with acetyl groups and stimulation of the production of butyric acid. An effective method for the increasing of butyric acid seems to be feeding with butyrylated starch (Bajka et al., 2010), however, this type of chemical modification has not been approved up to now (modified starches). RS2 or RS3 starches reveal positive effect on butyric acid cecal content in rats, however, no effect in case of pigs is observed (De Schrijver et al., 1999). The above presented results indicate the need for the further in vivo studies on RS4 starches based on cross-linked but not acetylated starches.

Previously described results regarding investigated starches reveals different kinetics of in vitro hydrolyses. Starch A, cross-linked only with adipic acid reaches maximum after 4 hour of hydrolysis, whereas dual crosslinked starch after 8 hour (Le Thanh-Blicharz et al., 2011). These in vitro observed prolongation of the time of hydrolysis could be the reason of beneficial physiological effect observed in vivo. However, this hypothesis needs the experimental verification. It could be also a recommendation for further research on the resistant starch.

\section{Acknowledgements}

The authors thank Malgorzata Tubacka for her assistance during animal study. The authors thank Robert Roberson for language correction.

This research was supported by the Polish Ministry of Science and Higher Education (N N312 093739).

\section{REFERENCES}

Anderson JW, Baird P, Davis RH, Ferreri S, Knudtson M, Koraym, Waters V, Williams L (2009) Health benefits of dietary fiber. Nutr Rev 67: 188-205.

Anioła J, Le Thanh J, Lewandowicz G (2009) Ocena strawności nowego preparatu skrobi modyfikowanej fizycznie w badaniach na szczurach. Zywn-Nauk Technol Ja 65: 170-174 (in Polish).

Bajka BH, Clarke JM, Topping DL, Cobiac L, Abeywardena MY, Patten GS (2010) Butyrylated starch increases large bowel butyrate levels and lowers colonic smooth muscle contractility in rats. Nutr Res 30: 427-434.

Bielecka M, Biedrzycka E, Majkowska A (2002). Selection of probiotics and prebiotics for synbiotics and confirmation of their in vivo effectiveness. Food Res Internat 35: 125-131.

Björck I, Gunnarsson A, Østergård K (1989) A study of native and chemically modified potato starch. Part II: Digestibility in the rat intestinal tract. Starch/Starke 41: 128-134.

Champ M (1992) Determination of resistant starch in foods and food products: interlaboratory study. Eur J Clin Nutr 46 (Suppl 2): 51-62.

Cheng HH, Lai MH (2000) Fermentation of resistant rice starch produces propionate reducing serum and hepatic cholesterol in rats. $J$ Nutr 130: 1991-1995.

Chezem JC, Furumoto E, Story J (1997) Effect of potato resistant starch on cholesterol and bile acid metabolism in rats. Nutr Res 17: 1671-1682.

Clarke JM, Bird AR, Topping DL, Lynne Cobiac L (2007) Excretion of starch and esterified short-chain fatty acids by ileostomy subjects after the ingestion of acylated starches. Am J Clin Nutr 86: 1146 -51 .

Clinical and Laboratory Standards Institute/NCCLS. Procedures for the Handling and Processing of Blood Specimens; Approved Guideline. Third Edition. 2004.

Commane D, Hughes R, Shortt C, Rowland I (2005) The potential mechanisms involved in the anti-carcinogenic action of probiotics. Mutation Res 591: 276-289.

Compendium of food additive specifications. Addendum 5: Modified starches. Prepared at the 49th JECFA (1997), superseding specifications prepared at the 35th JECFA (1989), published in FNP 49 (1990). Available on line: http://www.fao.org/docrep/W6355E/ w6355e0o.htm

Cummings JH, Stephen AM (2007) Carbohydrate terminology and classification. Eur J Clin Nutr 61: 5-18.

De Deckere E, Kloots W, van Amelsvoort J (1993) Resistant starch decreases serum total cholesterol and triacylglycerol concentrations in rats. J Nutr 123: 2142-2151.

De Schrijver R, Vanhoof K, Vande Ginste J (1999) Nutrient utilization in rats and pigs fed enzyme resistant starch. Nutr Res 19: 1349-1361.

Dżymała-Czyż S, Banasiewicz T, Tubacka M, Majewski P, Biczysko M, Kościński T, Drews M, Walkowiak J (2011) Inulin supplementation in rat model of pouchitis. Acta Biochim Polon 58: 381-384.

Ebihara K, Shiraishi R, Okuma K (1998) Hydroxypropyl-modified potato starch increases fecal bile acid excretion in rats. J Nutr 128: $848-854$.

Edwards CA, Gibson G, Champ M, Jensen B-B, Mathers J C, Nagengast F, Rumney C, Quehl A (1996) In vitro method for quantification of the fermentation of starch by human faecal bacteria. J Sci Food Agric 71: 209-217.

Englyst HN, Hudson GJ (1996) The classification and measurement of dietary carbohydrates. Food Chem 57: 15-21.

Ferguson MJ, Jones GP (2000) Production of short-chain fatty acids following in vitro fermentation of saccharides, saccharide esters, fructo-oligosaccharides, starches, modified starches and non-starch polysaccharides. I Sci Food Agric 80: 166-170.

Ferguson LR., Tasman-Jones C, Englyst H, Harris PJ (2000) Comparative effects of three resistant starch preparations on transit time and short-chain fatty acid production in rats. Nutr Cancer 36: 230-237.

Fuentes-Zaragoza E, Riquelme-Navarrete MJ, Sánchez-Zapata E, Pérez-Alvarez JA (2010) Resistant starch as functional ingredient: A review. Food Res Int 43: 931-942.

Fuentes-Zaragoza E, Sánchez-Zapata E, Sendra E, Says E, Navarro C, Fernández-López J, Pérez-Alvarez JA (2011) Resistant starch as prebiotic: A review. Starch/Starke 63: 406-415.

Hijova E, Chmelarova A (2007) Short chain fatty acids and colonic health. Bratsl Leki Listy 108: 354-358.

Juśkiewicz J., Zdużczyk Z., Fornal J (2005) Nutritional properties of tubers of conventionally bred and transgenic lines of potato resistant to necrotic strain of Potato virus Y (PVYN). Acta Biochim Polon 52: 725-729.

Kanazawa T, Atsumi M, Mineo H (2008) Ingestion of gelatinized potato starch containing a high level of phosphorus decreases serum and liver lipids in rats. I Oleo Sci 57: 335-343.

Kim MJ, Choi SJ, Shin SI, MR, Lee CJ, Kim Y, Cho WI, Moon TW (2008) Resistant glutarate starch from adlay: Preparation and properties Carbohyd Polym 74: 787-796. 
Kishida T, Nakai Y, Ebihara K (2001a) Hydroxypropyl-distarch phosphate from tapioca starch reduces zinc and iron absorption, but not calcium and magnesium absorption, in rats. J Nutr 131: 294-300.

Kishida T, Nogami H, Himeno S, Ebihara K (2001b) Heat moisture treatment of high amylose cornstarch increases its resistant starch content but not its physiologic effects in rats. J Nutr 131: 27162721.

Lajvardi A, Mazarin GI, Gillespie MB, Satchithanandam S, Calvert RJ (1993) Starches of varied digestibilities differentially modify intestinal function in rats. J Nutr 123: 2059-2066.

Lee KY, Yoo SH, Lee HG (2012) The effect of chemically-modified resistant starch, RS type-4, on body weight and blood lipid profiles of high fat diet-induced obese mice. Starch/Starke 64: 78-85.

Leszczyński W (2004) Resistant starch — classification, structure, production. Pol J Food Nutr Sci 13/54 S1 1: 37-50.

Le Thanh J, Blaszczak W, Lewandowicz G (2007) Digestibility vs. structure of food grade modified starches. EJPAU 10: \#10. Available Online: http://www.ejpau.media.pl/volume10/issue3/art10.html

Le Thanh-Blicharz J, Anioła J, Walkowski A, Lewandowicz G (2012) The assessment of the digestibility of RS4 modified starches in Wistar rats. Biuletyn Instytutu Hodowli $i$ Aklimatyzacii Roślin 266: 57-64 (in Polish).

Le Thanh-Blicharz J, Małyszek Z, Walkowski A, Drożdżyńska A, Lewandowicz G (2011) Rheological properties and texture of new RS4 type starch pastes. Postẹpy Nauki $i$ Technol Przem Rol-Spoż 66: 53-65 (in Polish).

Lopez HW, Levert-Verny MA, Coudray C, Besson C (2001) Class 2 resistant starch lower plasma, liver, improve mineral retention in rats. J Nutr 131: 1283-1289.

Marlett JA, Longacre MJ (1996) Comparison of in vitro and in vivo measures of resistant starch in selected grain products. Cereal Chem 73: 63-68.

Morais MB, Feste A, Miller RG, Lifschitz CH.(1996) Effect of resistant and digestible starch on intestinal absorption of calcium, iron, and zinc in infant pigs. Pediatr Res 39: 872-876.

Mun S-H, Shin M (2006) Mild hydrolysis of resistant starch from maize Food Chem 96: 115-121.

Napolitano A, Costabile A, Martin-Pelaez S, Vitaglione P, Klinder A, Gibson GR, Fogliano V (2009) Potential prebiotic activity of oligosaccharides obtained by enzymatic conversion of durum wheat insoluble dietary fibre into soluble dietary fibre. Nutr Metab Cardiovas 19: 283-290.

Orzeł D, Bronkowska M, Styczyńska M (2009) The influence of resistant starch RS4 in high-fat diets on calcium and phosphorus absorption in Wistar rats. Bromatol Chem Toksyk XLII: 1161-1166 (in Polish).

Perera A, Meda V, Tyler RT (2010) Resistant starch: A review of analytical protocols for determining resistant starch and of factors affecting the resistant starch content of foods. Food Res Int 43: 19591974.

Ranhotra GS, Gelroth JA, Glaser BK (1996) Effect of resistant starch on blood and liver lipids in hamsters. Cereal Chem 73: 176-178.
Ranhotra GS, Gelroth JA, Leinen BS (1997) Hypolipidemic effects of resistant starch in hamster is not dose dependent. Nutr Res 17: 317-323.

Sha XS, Zhang J. Xiang ZJ, Bin L, Jing L, Bin Z, Jiao YJ, Kun SR (2012) Preparation and physical characteristics of resistant starch (type 4) in acetylated indica rice. Food Chem 134: 149-154.

Sharma A, Yadav BS, Ritika A.(2008) Resistant Starch: Physiological Roles and Food Applications. Food Rev Int 24: 193-234.

Soral-Śmietana M, Wronkowska M (2004) Resistant starch - nutritional and biological activity. Pol J Food Nutr Sci 13/54 S1 1: 51-64.

Staniek H, Anioła J, Czarnocińska J (2005) Wpływ acetylowanego adypinianu diskrobiowego na wybrane wskaźniki żywieniowe szczura. Zywn-Nauk Technol Ja 43 (Suppl 2): 203-209.

Wronkowska M, Soral-Śmietana M, Krupa U, Biedrzycka E (2006). In vitro fermentation of new modified starch preparations - changes of microstructure and bacterial end-products. Ensyme and Mior Technol 40: 9-99.

Wronkowska M, Juśkiewicz J, Zduńczyk Z, Soral-Śmietana M, Krupa-Kozak U (2011) Influence of chemically-modified potato starch (RS type 4) on the nutritional and physiological indices of rats. Pol J Food Nutr Sci 61: 143-151.

Wootton M, Chaudhry MA (1979) Enzymic digestibility of modified starches. Starch/Starke 31: 224-228.

Vanhoof K, De Schrijver R (1998) The influence of enzyme-resistant starch on cholesterol metabolism in rats fed on a conventional diet. Brit J Nutr 80: 193-198.

Vanhoof KM, De Schrijver R (1997) Consumption of enzyme resistant starch and cholesterol metabolism in normo- and hypercholesterolemic rats. Nutr Res 17: 1331-1340.

Xie X, Liu Q, Cui SW (2006) Studies on the granular structure of resistant starches (type 4) from normal, high amylose and waxy corn starch citrates. Food Res Int 39: 332-341.

Zhang J, Wang Z-W (2009) Optimization of reaction conditions for resistant Canna edulis Ker starch phosphorylation and its structural characterization Ind Cros Prod 30: 105-113.

Zhao G, Nyman M, Jönsson JA (2006) Rapid determination of shortchain fatty acids in colonic contents and faeces of humans and rats by acidified water-extraction and direct-injection gas chromatography. Biomed Chromatogr 20: 674-82.

Zhou X, Kaplan M (1997) Soluble amylose cornstarch is more digestible than soluble amylopectin potato starch in rats. J Nutr 127: 1349-1356.

Zięba T, Juszczak L, Gryszkin A (2011a) Properties of retrograded and acetylated starch preparations. Part 2. Dynamics of saccharification with amyloglucosidase and rheological properties. LWT-Food Sci Technol 44: 1321-1327.

Zięba T, Szumny A, Kapelko M (2011b) Properties of retrograded and acetylated starch preparations Part 1. Structure, susceptibility to amylase and pasting characteristics. LWT-Food Sci Technol 44: 1314-1320. 